\title{
Lawrence v. Texas Overrules San Antonio School District v. Rodriguez
}

\author{
by John Ryskamp
}

\begin{abstract}
We certainly don't know everything about the ramifications of Lawrence $v$. Texas, ${ }^{1}$ particularly since it seems only to have been litigated in the sexuality/family context. However, we do know some things about it. For example, we know that Justice Scalia is wrong in his dissent when he claims to have found the "ground on which the Court squarely rests its holding: the contention that there is no rational basis for the law here under attack." 2 The sodomy law should have been upheld under this standard. Lawrence v. Texas, 539 US 558, 599 (2003). However, what the Court actually said is that the Texas sodomy law "furthers no legitimate state interest." Id., at 560. Here are the two levels of scrutiny from which this test is drawn:
\end{abstract}

MINIMUM SCRUTINY: rationally relates to a legitimate government purpose INTERMEDIATE SCRUTINY: substantially furthers an important government purpose

A glance at the relevant scrutiny test shows what the Court has done: it has taken the "furthers" prong from intermediate scrutiny and the "legitimate" from minimum scrutiny. This hybrid is not a scrutiny regime test, nor does the Court claim that it is.

Nor is this test affecting sexual rights or family rights. It is a test for the liberty right. This should not be surprising, since the only way the Court could find a pure right to liberty — as opposed, say, to a fundamental right to right to liberty — was to detach it altogether from the scrutiny regime. This also clarifies a confusion about the case: the reason the Court never calls the Lawrence liberty right a fundamental right or a right to privacy: that would place it under the scrutiny regime, which is what the Court does not want to do. To be sure, the Court, in discussing various cases, says that they stand for the "fundamental proposition that the law impaired the exercise of their personal rights," 3 or the right to "make certain fundamental decisions"4 or that "the protection of liberty under the Due Process Clause has a substantive dimension of fundamental significance in defining the rights of the person."

So, on what did the Court base its finding of a right to liberty in Lawrence? Although the case is never mentioned, the Court based Lawrence on the idea that the scrutiny regime applied to all facts, but that its only justification was a baseless restriction of liberty in West Coast Hotel v. Parrish. In order to establish a right to liberty, the Court had to remove liberty from the scrutiny regime, and that could only be done by overruling the scrutiny regime itself. The scrutiny regime had been established in West Coast Hote

\footnotetext{
${ }^{1} 539$ US 558 (2003).

${ }^{2} I d$., at 599 .

${ }^{3}$ Id., at 565 .

${ }^{4} \mathrm{Id}$., at 565 .

${ }^{5} \mathrm{Id}$., at 565 .
} 
by a "demotion" of liberty to an interest. Part of the problem of understanding Lawrence is that we do not have a clear understanding of the doctrinal basis of minimum scrutiny. For that, we need to re-examine the case which articulated that basis and promulgated the scrutiny regime, West Coast Hotel v. Parrish. $^{6}$

It has not been noted previously that the premise of West Coast Hotel is a "demotion" of liberty from an individually enforceable right to an interest, based on a highly dubious analysis of liberty from a Court frightened that it was about to lose power because it had found unconstitutional, health and welfare regulation which at issue-in the form of a state's minimum wage law-in West Coast Hotel. We should not be surprised that the Court felt obliged to impose a whole new scheme of adjudicating the Constitution: it was only one of several which had occurred. As one commentator has noted:

At one point in its history American constitutional jurisprudence presumed that the distinction between "judicial" and "political" questions was intelligible; at another point it presumed that the boundary between public power and private rights could coherently be traced; at another it presumed that there was a clear difference between the sort of legislation that required heightened and the sort that only required minimal scrutiny. Those presumptions did not come from the Constitution or any other legal source. They came from a set of shared social and political attitudes that shaped conceptions of the role of the judiciary in American constitutionalism. As those attitudes changed, presumptions changed with them. A robust constitutional principle of departmental discretion gave way to judicial boundary tracing which gave way to judicially fashioned levels of scrutiny. None of those regimes of constitutional interpretation should be regarded as cast in stone. None should be regarded as intrinsically superior to the others. The scrutiny regime has been with us for approximately 70 years. It may have exhausted itself as a helpful technique of constitutional interpretation. If we understand its historical origins, perhaps we can understand its contingent status. ${ }^{7}$

The demise of the regime is well under way, even if we are in something of a quandary as to where that leaves us. West Coast Hotel sustained a state minimum wage law for women and minors. In sustaining the law, the Court stated that "the Constitution does not recognize an absolute and uncontrollable liberty. Liberty in each of its phases has its history and connotation. But the liberty safeguarded is liberty in a social organization which requires the protection of law against the evils which menace the health, safety, morals, and welfare of the people. Liberty under the Constitution is thus necessarily subject to the restraints of due process, and regulation which is reasonable in relation to its subject and is adopted in the interests of the community is due process." 8 The claimed authority for the law was merely that "the statute is a reasonable exercise of the police power of the state." Nevertheless, the Court felt moved to assume, without deciding, that minimum wage laws were an aspect of due process and that due process conflicted with liberty. It further assumed, again without deciding, that indicia of liberty are

1. absoluteness combined with uncontrollability;

2. "phases;"

\footnotetext{
${ }^{6} 300$ US 379 (1937).

7 G. Edward White, "Historicizing Judicial Scrutiny," http:/law.bepress.com/uvalwps/uva publiclaw/art31, 142.

${ }^{8}$ West Coast Hotel at 391.

${ }^{9} I d$., at 389.
} 
3. "history and connotation;" and

4. "evils which menace the health, safety, morals, and welfare of the people."

Where it picked up these bizarre prejudices, no one knows. Adept at describing liberty, the Court felt that the Constitution "does not recognize" liberty as a fact. This nonrecognition was also the recognition of the Court's new "liberty," the indicia of which are

1. regulation

2. reasonably relating to

3. a subject.

And what is the subject? The same one the Constitution "does not recognize." Passing by this anomaly, we ask: for the fact of liberty, the Court substituted what fact? The regime- the "social organization." That is what the Constitution recognized. Where the Court picked up this additional bizarre prejudice - and where it found authority for this question begging - no one knows, either. It is worth noting that the Court's prejudice against liberty is a view of the Constitution as pre- or proscriptive, rather than descriptive. It assumes, without deciding, that either liberty or due process is "subject" to the other and assigns the definition of "subject" to another term which is undefined, the "social organization."

Already, the Court has gone so far with unexamined assumptions and simple speculations that the decision would clearly not pass muster in today's legal environment: if it were not precedent, everyone would laugh at it. No first year law student could get away with it.

Politics has intervened to produce a wildly erratic holding. It is ducking and shuffling by a Court on the run from Court-packing, the threat from President Franklin Roosevelt to get an increase in the number of the justices on the Court and then select nominees who will uphold the constitutionality of health and welfare regulation. Among the Court's other damaging assumptions in West Coast is that prior to the vindication of the minimum wage law, liberty had somehow been an individually enforceable right. This is another unstated assumption which is nowhere proved or even discussed, except by implication in the context of the Court's stated - and equally unsupportedassumptions about liberty. The decision is an unholy mess. Indeed, since there is no reasoned discussion by the Court of liberty in its pre-West Coast state, it is entirely unclear that West Coast "demoted" liberty in the first place or what the Court felt it was "demoting."

What is important to note is that the "demotion"- or whatever the Court is doing - of liberty is the sole basis on which the Court sustains the minimum wage law and establishes the scrutiny regime. Viewed exclusively as a matter of legal technique, the most important aspect of West Coast Hotel is that by "demoting" liberty to an "interest," the Court constructed for itself a "place" to put all facts-among them, maintenance - with which its manifestly limited understanding made it incapable of coping; the history of the "minimum scrutiny" regime is the history of the Court's progressive refusal to let anyone else deal with such facts, either. Clearly, that idea was not going to be tolerable forever, especially given its glaringly problematic basis. 
Actually, the unspoken basis of West Coast Hotel was Marbury v. Madison, ${ }^{10}$ which was nowhere mentioned. The law in question in Marbury - which might have permitted the Court to order the Executive to turn over a commission in violation of Court duties laid out in the Constitution-was clearly unenforceable, not simply because the contemporary Administration might have refused, but also because future Administrations might refuse. How does unenforceability play into West Coast Hotel? The West Coast Hotel Court overruled an earlier case, Adkins v. Children's Hospital, ${ }^{11}$ in which minimum wage laws had been found unconstitutional. Adkins was from 1923; West Coast Hotel was from 1937. What had happened in the interim? Here the Court was at least frank: "The importance of the question, in which many states having similar laws are concerned, the close division by which the decision in the Adkins Case was reached, and the economic conditions which have supervened, and in the light of which the reasonableness of the exercise of the protective power of the state must be considered, make it not only appropriate, but we think imperative, that in deciding the present case the subject should receive fresh consideration."12 The ban on minimum wage laws had been ignored and would be ignored. Adkins was flat out unenforceable. Something was wrong with the Court's jurisprudence when it issued decisions which could not, under any circumstances, be enforced. This linked West Coast Hotel with Marbury, in which the Court also refused to go along with a law which could not, under any circumstances, be enforced. In West Coast Hotel, the law was the Court's own ban on health and welfare legislation.

The case of United States v. Carolene Products Co., ${ }^{13}$ is famous for its footnote putatively exempting from the "minimum scrutiny" regime some facts in some contexts. But Carolene Products itself gives the lie to that "exemption." Carolene sustained a Federal policy preventing from interstate commerce, milk products with unwholesome substituted ingredients. But the Court here does not apply minimum scrutiny analysis. It treats as facts, "public health, morals, or welfare," 14 and sustains the law because it feels those are important facts. As the Court notes, state law permitting the shipment of such products, was not based on any facts relating the products to the policy permitting the shipment of them; the Court didn't care that there might be a state purpose. The facts were that the products had "been stripped of elements essential to the maintenance of health.... [The use of them] is generally injurious to health and facilitates fraud on the public," "15 the product marketed "in imitation or semblance of milk...."16 It has not been previously noted that the Court was able to intervene in this way because, in the first instance, in West Coast Hotel, its demotion of "liberty" was problematic.

Nevertheless, the Court in this case was busily working, laying the groundwork for an individually enforceable right to maintenance, in the following ways:

\footnotetext{
${ }^{10} 5$ US (1 Cranch) 137, 176 (1803).

${ }^{11} 261$ US 525 (1923).

${ }^{12}$ West Coast Hotel at 390.

${ }^{13} 304$ US 144 (1938).

${ }^{14} \mathrm{Id}$., at 147.

${ }^{15} \mathrm{Id}$., at 149 .

${ }^{16} \mathrm{Id}$., at 151 .
} 
1. the fact was that the Federal Government had passed the ban on the substitute ingredients. Whatever previous law might have held this to be forbidden, the fact was that the Government was proceeding to enforce it. To overturn the ban would be to engage in the promulgation of unenforceable doctrines, which the Court had already found inadvisable in West Coast Hotel;

2. the Court held that "public health, morals, or welfare"- take your pick —are facts and the Government is proceeding to vindicate those facts;

3. the Court held that maintenance is an indicium of health, simply on the basis that the Government had passed the ban; and, finally,

4. the Court held that health is an indicium of maintenance.

The only remaining question was: where does liberty figure in all of this?

One famous tenet of Carolene is that government needn't tailor its legislation precisely to facts. The Court attempted to make precise this imprecision. The Court said that "Appellee raises no valid objection to the present statute by arguing that its prohibition has not been extended to oleomargarine or other butter substitutes in which vegetable fats or oils are substituted for butter fat. The Fifth Amendment has no equal protection clause, and even that of the Fourteenth, applicable only to the states, does not compel their Legislatures to prohibit all like evils, or none. A Legislature may hit at an abuse which it has found, even though it has failed to strike at another." ${ }^{17}$ But this allowance for legislative "discretion" was inherently contradictory. On the one hand, "a statute would deny due process which precluded the disproof in judicial proceedings of all facts which would show or tend to show that a statute depriving the suitor of life, liberty, or property had a rational basis." ${ }^{18}$ On the other, there "may be narrower scope for operation of the presumption of constitutionality when legislation appears on its face to be within a specific prohibition of the Constitution, such as those of the first ten Amendments" (this being the famous footnote). ${ }^{19}$ Since liberty had been "demoted" to minimum scrutiny, it was exempted from "narrower" operation - that is, the Court gave back to the political system that substituting of private for government purpose, which it seemed to have taken away. So what were, in fact, "narrow," "scope" and liberty? If the facts of "public health, morals, or welfare" enjoyed more scrutiny under the rubric of liberty, as did all legislative policies relating to them, it was anomalous that liberty itself enjoyed only minimum scrutiny. Thus, the Court's own factual findings began to force liberty once again to the surface-assuming, again, that it had ever submerged it. And what, for that matter, were, in fact, private health, morals and welfare?

More specifically, what was the relationship between liberty and "public morals?" It took a brief sixty after Carolene Products, but that precise question was finally posed in Lawrence and in it the Court abandoned the scrutiny regime kit and caboodleprivacy, fundamental rights, government purpose, and all the rest of it. The Lawrence

\footnotetext{
${ }^{17} I d$., at 151.

${ }^{18} \mathrm{Id}$., at 151.

${ }^{19} I d$., at 155 (footnote 4).
} 
case overturned Bowers v. Hardwick. ${ }^{20}$ In Bowers, the Court had sustained Georgia's law against sodomy as applied to two consenting adult males. What didn't Georgia like about sodomy?

\section{1. absoluteness combined with uncontrollability;}

It is sex, and any kind of sex: "any kind of private sexual conduct between consenting adults...." It's also "painful.",22

\section{2. "phases;"}

It both is and is not, sex: "facetious.",23

\section{3. "history and connotation;"}

Georgia laws ban it and "have done so for a very long time."24

\section{4. and "evils which menace the health, safety, morals, and welfare of the people."}

It provides "[ $\mathrm{n}] \mathrm{o}$ connection between family, marriage, or procreation....",25

In short, Georgia didn't like sodomy because, for Georgia, sodomy was liberty. By the way, is it?

The point is that, as we can see from the criteria above, Georgia's criteria for liberty and its mandate regarding liberty came from the Supreme Court. For the Supreme Court, too, sodomy was liberty, and therefore had to be suppressed. The need for doing so "had [been] painfully demonstrated by the face-off between the Executive and the Court in the 1930's." 26 This was Franklin Roosevelt's threat to pack the Court with more justices in order to get New Deal legislation found constitutional. And which branch of government, we ask, had suffered that pain? The Supreme Court. And how had the Court alleviated that curious pain? By sustaining, in West Coast Hotel, a minimum wage law in a tradeoff for the right to suppress liberty: again, the criteria listed above.

The Lawrence Court examined the facts as if liberty were a fact just like "public health, morals or welfare." So whatever else the Court does when it affirms liberty by striking down a law which "further no legitimate state interest," it clearly conducts a factual inquiry. The Court makes it clear that the test is not its last word on liberty adjudication: "Had those who drew and ratified the Due Process Clauses of the Fifth Amendment or the Fourteenth Amendment known the components of liberty in its manifold possibilities, they might have been more specific. They did not presume to

\footnotetext{
${ }^{20} 478$ US 186 (1986).

${ }^{21} I d$., at 191.

${ }^{22} I d$., at 194.

${ }^{23} I d$., at 194.

${ }^{24} I d$., at 190 .

${ }^{25} \mathrm{Id}$., at 191.

${ }^{26} \mathrm{Id}$., at 194.
} 
have this insight. They knew times can blind us to certain truths and later generations can see that laws once thought necessary and proper in fact serve only to oppress. As the Constitution endures, persons in every generation can invoke its principles in their own search for greater freedom., 27

The Texas Constitution includes this provision: "A general diffusion of knowledge being essential to the preservation of the liberties and rights of the people, it shall be the duty of the Legislature of the State to establish and make suitable provision for the support and maintenance of an efficient system of public free schools." ${ }^{28}$ For its part, the Lawrence right to liberty is applicable to the States under the Due Process Clause of the Fourteenth Amendment. The question in San Antonio School District ${ }^{29}$ was, whether the state school finance system violates the Equal Protection Clause on the basis of a right to education? The Court answered, no because there is no fundamental right to education under the Fourteenth Amendment.

However, after Lawrence, the right to education in Texas must be seen as a Federal Equal Protection right, overruling San Antonio School District. "Fundamental" analysis under the scrutiny regime, is used by the Court in the latter case. Under Lawrence, however, the scrutiny regime is not used to adjudicate any part of the Constitution, so we do not ask, with respect to education under Equal Protection, whether there is a "fundamental" right to education. Instead, we ask, what is the education right under Equal Protection? We know that Texas has found that education assumes education is essential to liberty. Since liberty is an Equal Protection right, the question becomes, under Federal Equal Protection whether the Texas school finance system is essential to education? It is the Equal Protection liberty right which allows the finance question to be adjudicated on the Federal level on the basis of its essential relation to education.

\footnotetext{
${ }^{27}$ Lawrence at 578-579.

${ }^{28}$ Texas Constitution, Article 7, Section 1. The entire constitution is online at http://www.capitol.state.tx.us.

${ }^{29} 411$ US 1 (1973).
} 